УДК 582.287.2. (571.65)

\title{
ГАСТЕРОМИЦЕТЫ МАГАДАНСКОЙ ОБЛАСТИ
}

\author{
Н. А. Сазанова, Ю. А. Ребриев ${ }^{2}$ \\ ${ }^{1}$ ФГБУН Институт биологических проблем Севера ДВО РАН, г. Магадан \\ ${ }^{2}$ Южный научный иеентр РАН, г. Ростов-на-Дону \\ E-mail:nsazanova_mag@mail.ru; rebriev@yandex.ru
}

\begin{abstract}
Приводятся результаты обработки многолетних сборов гастероидных базидиомицетов Магаданской области, хранящихся в Гербарии Института биологических проблем Севера ДВО PAH (MAG). Получены данные о 26 таксонах из трех порядков, среди которых отмечены как широко распространенные, так и редкие виды. Выявлено 12 видов, новых для региона, в том числе 1 - для Восточной Азии и 1 - для Евразии. Значительно расширены сведения о видовом разнообразии родов Bovista и Lycoperdon, внесены изменения в список видов рода Calvatia.
\end{abstract}

\section{Ключевые слова: гастеромицеты, биоразнообразие, редкие виды, Магаданская область, север Дальнего Востока России.}

DOI: 10.34078/1814-0998-2019-4-55-65

\section{ВВЕДЕНИЕ}

Гастеромицеты - полифилетическая группа таксонов базидиальных грибов с закрытыми плодовыми телами. Первоначально они рассматривались как единый таксон - класс Gasteromycetes. В новых системах, разрабатываемых на основе данных молекулярной филогенетики, видовое разнообразие гастероидных базидиомицетов распределяется между шестью порядками класса Agaricomycetes.

Эта группа грибов широко представлена по всему миру, но наиболее многочисленна и разнообразна в субтропических, степных и пустынных районах. Для территории России известно около 200 видов из 50 родов (Ребриев и др., 2010). Степень изученности гастероидных грибов природных зон России не одинакова. В широтном отношении лучше изучены южные районы, где разнообразие гастероидных грибов значительно выше, в долготном - Европейская часть России. В последнее время выходит достаточно много публикаций с новыми данными по Западной и Центральной Сибири (Агафонова и др., 2011; Горбунова, Ребриев, 2016; и др.). Выделены редкие виды гастеромицетов для Азиатской части и в целом для России (Горбунова, Ребриев, 2017; Ребриев и др., 2018). Появляются публикации, содержащие, в том числе, и сведения о гастеро-

(С Сазанова Н. А., Ребриев Ю. А., 2019 мицетах дальневосточного Севера (Crous et al., 2019; Volobuev et al., 2019). Тем не менее разнообразие этой группы по-прежнему остается слабоизученным.

На современном уровне многие роды гастероидных базидиомицетов подвергаются критическому пересмотру, в том числе и в связи с активным применением в систематике молекулярногенетических методов и с описанием вновь открытых видов. Просмотр региональных коллекций позволяет уточнить накопленную информацию, выявить своеобразные черты представленной микобиоты, расширить данные о распространении и экологии видов.

\section{МАТЕРИАЛ И МЕТОДЫ}

Материалом для данных исследований послужили образцы, хранящиеся в Гербарии ИБПС ДВО РАН (MAG). В микологической коллекции насчитывается более двух сотен частично определенных образцов, собранных в окрестностях г. Магадана и районах Магаданской области в течение многих лет. Сборами охвачены все основные ландшафты с характерными комплексами растительности.

Вследствие сурового климата и многолетней мерзлоты в Магаданской области преобладает достаточно однообразная растительность с хорошо выраженной вертикальной поясностью. Фоновыми сообществами являются леса и редколесья из лиственницы Каяндера (Larix cajan- 
deri), с подлеском из кедрового (Pinus pumila) и ольхового (Duschekia fruticosa) стлаников, березы Миддендорфа (Betula middendorffii) и разных видов ив (Salix spp.). Большие площади низин занимают мохово-лишайниковые кочкарные тундры с участием березы тощей (Betula exilis) и бугристо-мочажинные болота. В поймах рек распространены лиственные леса из тополя (Populus suaveolens) и чозении (Chosenia arbutifolia), ивняки, в низинах - заболоченные осокововейниковые луга. На старопойменном уровне развиты высокопродуктивные лиственничные леса с участием березы плосколистной (Betula platyphylla). С подъемом в горы происходит постепенное изреживание древостоя, а затем лиственничные редколесья последовательно замещаются поясом кедрового и ольхового стлаников и ерниками. Вершины гор заняты кустарничковолишайниковыми тундрами и каменистыми пустынями. Вдоль североохотского побережья по приморским склонам растут каменноберезовые леса (из Betula lanata), зачастую смешанные с лиственницей, кедровым стлаником и ольховником. На приморских террасах господствуют кедровые и ольховые стланики, ерники, сухие кустарничково-лишайниковые тундры. В регионе сохранились небольшие реликтовые участки из ели сибирской (Picea obovata) в долине p. Яма и обедненные варианты степных сообществ с небольшими рощами из осины (Populus tremula), наиболее развитые в верховьях Колымы (Север..., 1970; Синельникова, 2009). Значительные площади охотско-колымских ландшафтов (до 40\%) заняты зарастающими и свежими гарями (Андреев, 2013). Продолжительность вегетационного периода в среднем составляет около 100 дней, но в последние десятилетия имеет тенденцию к небольшому увеличению (Синельникова, Пахомов, 2015).

По флористическому районированию СевероВосточной Азии территория Магаданской области относится к Северо-Охотской провинции Восточно-Сибирской подобласти Бореальной флористической области (Юрцев, 1974), характеризуется «устойчивым сосуществованием океанических и континентальных видов и их комплексов» и рассматривается в подзоне гипоарктической (северной) тайги.

Идентификацию видов гастеромицетов осуществляли на базе Южного научного центра РАН (Ростов-на-Дону). При определении использовали традиционные морфологические методы выявления макро- и микроскопических признаков: окраску и размеры структур экзоперидия, размеры и орнаментацию спор, размеры и форму ветвления гиф капиллиция, другие микроструктурные характеристики. Материал изучен с использованием бинокуляров и световых микроскопов (увеличение $400^{\times}$и $1500^{\times}$), при необходимости электронного микроскопа Carl Zeiss EVO-40 XVP. Препараты просмотрены в 5\%-ном раствоpe $\mathrm{KOH}$, согласно стандартным методикам и требованиям определительных ключей.

Образцы хранятся в Гербарии ИБПС ДВО РАН (MAG), ряд дубликатов переданы в частную коллекцию Ю. А. Ребриева (YuR), некоторые трудно определяемые образцы оставлены там же на временное хранение.

\section{РЕЗУЛЬТАТЫ}

В результате ревизии и критической обработки коллекции идентифицировано 26 таксонов, относящихся к 5 семействам и 3 порядкам. Некоторые образцы болетальных гастеромицетов (пор. Boletales) определены до рода. Ниже приводится конспект биоты гастероидных базидиомицетов, выявленных на данный момент на территории Магаданской области. Приведены ссылки на образцы. Новые для региона виды помечены звездочкой*, Восточной Азии - **, Евразии - ***. Названия таксонов даны в соответствии с базой данных Index Fungorum [http://www.indexfungorum. org/names/Names.asp]. В случае недавнего изменения действующего названия таксона в скобках приводится наиболее часто употребительный синоним.

Распространение вида на территории России приводится на основании работ Ю. А. Ребриева (2007, 2013, 2016), Ю. А. Ребриева, К. В. Двадненко (2017). Акцентируется внимание на распространении вида в Дальневосточном регионе и в сопредельной с Магаданской областью Республике Саха (Якутия). Общее распространение выверено по базе данных Global Biodiversity Information Facility (GBIF) [https://www.gbif. org/species/5] с использованием работ (Шварцман, Филимонова, 1970; Сосина, 1973; Kreisel, 2001).

Пop. AGARICALES, Cем. Agaricaceae

Apioperdon pyriforme (Schaeff.) Vizzini [ $\equiv L y$ coperdon pyriforme Schaeff.] - Дождевик грушевидный. Рис. 1.11.

Смешанные пойменные, долинные и склоновые леса, ольховниковые заросли, приморские луга, на валежной древесине, сухостое и пнях берез каменной и плосколистной, чозении, тополя, ольховника, на газонах, по обочинам дорог. Плодоношение в июне - сентябре, встречается часто, образует обильные скопления базидиом. Известные местонахождения: г. Магадан (MAG 3033), окр-ти г. Магадана - окр-ти Горнолыжной базы (MAG 2165, 2166, 4232, 4234), близ птицефабрики «Северная» (MAG 2164); Ольский - окр-ти пос. Ола (MAG 5039), долина р. Яма (MAG 2167), п-ов Кони (MAG 3636), о. Завьялова (MAG 2946), о. Спафарьева (MAG 4005), Арманский перевал 

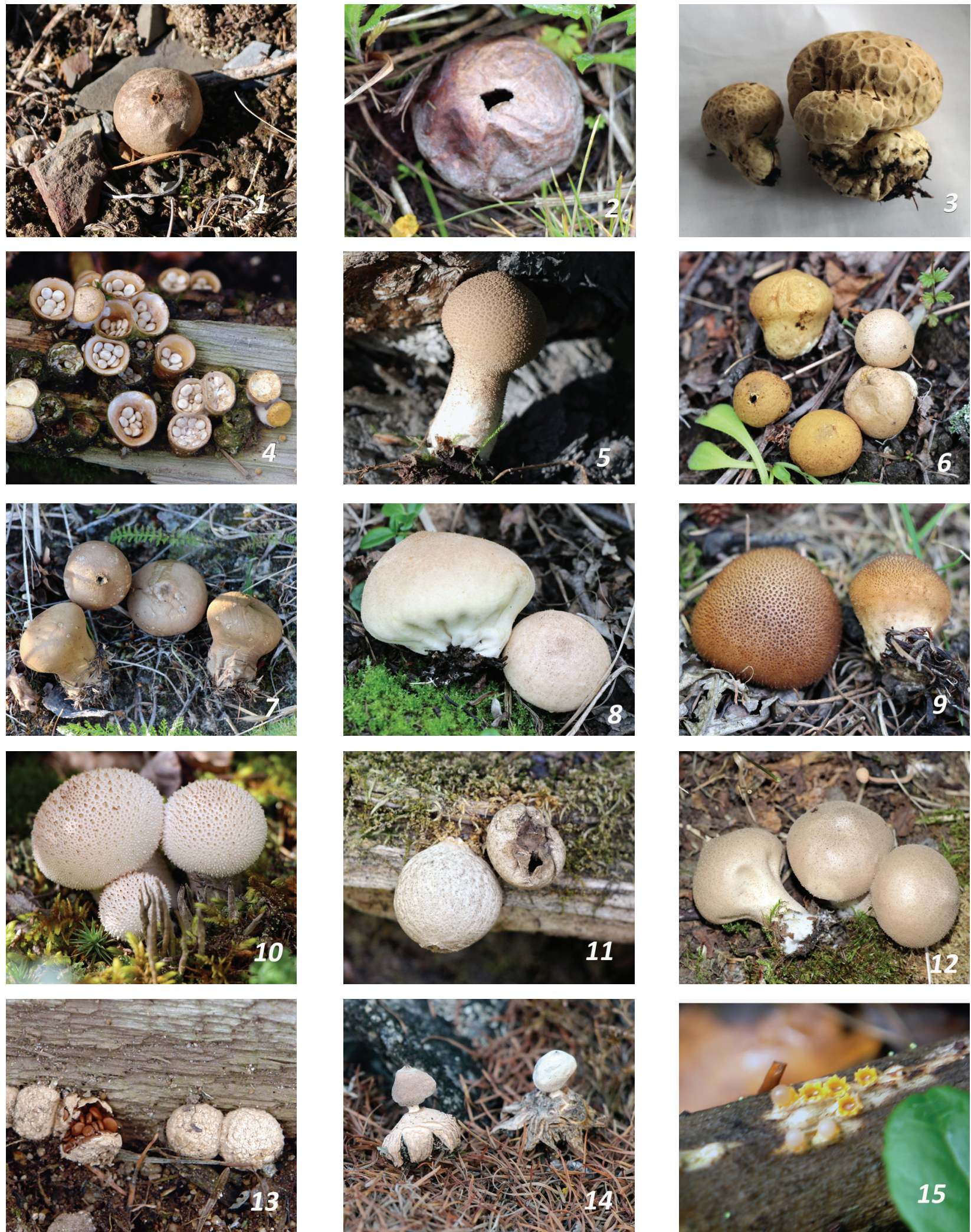

Puc. 1. Виды гастероидных базидиомицетов: 1 - Bovista aestivalis, 2 - Bovista nigrescens, 3 - Calvatia turneri, 4-Crucibulum laeve, 5 -Lycoperdon excipuliforme, 6-Lycoperdon lambinonii, 7 -Lycoperdon lividum, 8 -Lycoperdon molle, 9-Lycoperdon nigrescens, 10 -Lycoperdon perlatum, 11 - Apioperdon pyriforme, 12 - Lycoperdon umbrinum, 13 - Nidularia deformis, 14 - Geastrum minimum, 15 - Sphaerobolus stellatus. Фото Н. А. Сазановой

Fig. 1. Species of gasteroid basidiomycetes: 1 -Bovista aestivalis, 2 - Bovista nigrescens, 3 - Calvatia turneri, 4 Crucibulum laeve, 5 -Lycoperdon excipuliforme, 6-Lycoperdon lambinonii, 7 -Lycoperdon lividum, 8 -Lycoperdon molle, 9 -Lycoperdon nigrescens, 10 -Lycoperdon perlatum, 11 -Apioperdon pyriforme, 12 - Lycoperdon umbrinum, 13 - Nidularia deformis, 14 - Geastrum minimum, 15 - Sphaerobolus stellatus. Photo by N. A. Sazanova 
(MAG 4586, 4884, 4938, 4985), Янский лиман (MAG 5030), Среднеканский - пойма р. Колыма близ устья р. Толокончан (MAG 3365), окр-ти пос. Сеймчан (MAG 5132, 5134, 5135), Ягоднинский - окр-ти пос. Эльген (MAG 4007) и Тенькинский - окр-ти пос. Усть-Омчуг (MAG 4221), полевой базы «Оротук» (MAG 4022) районы.

Распространение в России: Европейская часть, Кавказ, Урал, Западная и Восточная Сибирь (в т. ч. Республика Саха (Якутия), Дальний Восток (Амурская обл., Еврейская АО, Камчатский (Корякия) и Приморский края, Сахалинская обл., Чукотский АО).

Общее распространение: встречается на всех континентах.

*Bovista aestivalis (Bonord.) Demoulin - Пopховка летняя. Рис. 1.1.

Каменноберезняки, лиственничные редины и редколесья, остепненные склоны, высокопойменные луговины, на почве. Может расти как в естественных, так и нарушенных местообитаниях, предпочитает открытые хорошо прогреваемые места. Плодоношение в июле-августе, встречается не часто. Известные местонахождения: окр-ти г. Магадана - Нагаевская сопка (MAG 4074); Хасынский - 127-й км Колымской трассы (MAG 5029), Тенькинский - верховья р. Колыма, окр-ти полевой базы «Оротук» (MAG 3280), причал «Елочка» в 10-12 км ниже с. Оротук (MAG 4021), Сусуманский - 795-й км федеральной трассы «Колыма» (MAG 5155), окр-ти пос. Мяунджа, г. Лысая (MAG 5161, 5165) районы.

Распространение в России: Европейская часть, Кавказ, Урал, Западная и Восточная Сибирь (в т. ч. Республика Саха (Якутия)), Дальний Восток (Амурская обл., Еврейская АО, Приморский край).

Общее распространение: Европа, Азия, Северная и Южная Америка, Австралия.

*Bovista limosa Rostr. - Порховка илистая.

Лиственничные редколесья, антропогенные луговины, поймы рек - на косах и в разреженных тополево-чозениевых лесах, на песчаногалечной почве. Плодоношение в июле-августе, встречается редко. Известные местонахождения: окр-ти г. Магадана - окр-ти пос. Снежная Долина (MAG 2161); Ольский район - о. Завьялова (MAG 3023), пойма ср. теч. р. Челомджа (MAG 4012).

Распространение в России: Урал, Западная Сибирь, Дальний Восток (Камчатский край, Чукотский $\mathrm{AO}$ ).

Общее распространение: Европа, Азия, Сeверная Америка.

Bovista nigrescens Pers. - Порховка чернеющая. Рис. 1.2.

Приморские луга и кустарничковые тундры, антропогенные луговины, опушки лиственнич- ных редколесий и пойменных тополево-чозениевых лесов, на почве. Плодоношение в июле сентябре, встречается часто в приохотских районах области. Известные местонахождения: окрти г. Магадана - Новая Веселая, распадок Кедровый ключ (MAG 2703, 3535, 4027), 14-й км (MAG 4020) и 19-й км (MAG 3492) федеральной трассы «Колыма», окр-ти пос. Снежная Долина (MAG 2156, 4009); Ольский - о. Завьялова (MAG 2945, 2953, 2954), окр-ти оз. Чистое (MAG 1338), устье р. Ола (MAG 4422, 4581), Янский лиман (MAG 4087) и Северо-Эвенский - окр-ти пос. Северо-Эвенск (MAG 4395, 4386) районы.

Распространение в России: Европейская часть, Кавказ, Урал, Западная и Восточная Сибирь (в т. ч. Республика Саха (Якутия), Дальний Восток (Камчатский край, Сахалинская обл.).

Общее распространение: Европа, Азия, Северная и Южная Америка, Австралия.

Bovista plumbea Pers. - Порховка свинцовосерая.

Антропогенные луговины, на почве. Предпочитает унавоженную почву. Плодоношение в августе, встречается редко. Известные местонахождения: окр-ти г. Магадана - Новая Веселая, распадок Кедровый ключ (MAG 3236); Ольский район - окр-ти оз. Соленое (MAG 5159 ).

Распространение в России: Европейская часть, Кавказ, Урал, Западная и Восточная Сибирь (в т. ч. Республика Саха (Якутия), Дальний Восток (Амурская обл., Приморский и Хабаровский края).

Общее распространение: вид указан для всех континентов, кроме Антарктиды.

**Bovista tomentosa (Vittad.) Quel. - Порховка войлочная.

Щебнистые склоны с остепнением, пустыри, обочины полей, антропогенные луговины, на уплотненной почве. Предпочитает антропогенные местообитания. Плодоношение в июлеавгусте, встречается редко. Известные местонахождения: окр-ти г. Магадана - м-н Нагаево (MAG 2704); Хасынский - 152-й км Колымской трассы (MAG 3278), Среднеканский - окр-ти с. Колымское (MAG 1426), Тенькинский - верховья р. Колыма, в 10-12 км ниже с. Оротук (MAG 4021) районы.

Распространение в России: Европейская часть, Урал, Западная Сибирь. Новый вид для Восточной Азии (Восточная Сибирь и Дальний Восток).

Общее распространение: Европа, Азия, $\mathrm{Ce}$ верная Америка.

Calvatia cretacea (Berk.) Lloyd. - Головач меловой.

Приморские пятнистые тундры с ивой клинолистной (Salix sphenophylla). Плодоношение в июне-июле, встречается редко. Известные ме- 
стонахождения: Ольский район - о. Завьялова (MAG 3020).

Распространение в России: север Европейской части, Урал, Западная и Восточная Сибирь (Республика Саха (Якутия), Дальний Восток (Чукотский $\mathrm{AO})$.

Общее распространение: Европа, Азия, Северная и Южная Америка.

*Calvatia turneri (Ellis et Everh.) Demoulin et M. Lange - Головач Тернера. Рис. 1.3.

Лиственничные леса и редколесья, разреженные заросли кедрового стланика, приморские и горные кустарничковые и кустарничково-лишайниковые тундры, песчаные косы с ивами и шикшей (среди Salix polaris, Diapensia obovata, Arctous alpina, Empetrum nigrum), на почве в долинах рек, приморских террасах и горных склонах, поднимается до 1000-1600 м н. у. м. Плодоношение в июле - сентябре, встречается часто. Известные местонахождения: Ольский - окр-ти оз. Чистое (MAG 3992, 4010), п-ов Пьягина (MAG 3035), о. Спафарьева (MAG 5038), Хасынский - окр-ти стационара «Рангифер» (MAG 3997, 3998), Ольское плато (MAG 4031), Яблоновый перевал (MAG 4493), Среднеканский - окр-ти г. Эзоп (MAG 3512), Сусуманский - окр-ти оз. Момонтай (MAG 5170, 5171) и Тенькинский - хр. Б. Анначаг, верховья р. Эльгенья (MAG 2158) и руч. Левый Восьмиозерный (MAG 4023, 4030) районы. В гербарной коллекции также хранится образец, собранный на территории Республики Саха (Якутия), долина р. Делянкир (MAG 5166) и образцы с Чукотки.

Распространение в России: север Европейской части, Урал, Западная и Восточная Сибирь (Республика Саха (Якутия), Дальний Восток (Камчатский край, Чукотский АО).

Общее распространение: Европа, Азия, Северная Америка.

Crucibulum leave (Huds.) Kambly - Круцибулюм гладкий. Рис. 1.4.

Рудеральные местообитания, реже пойменные и каменноберезовые леса, на гниющей обработанной древесине, заборах, мусоре, опилках, реже на ветках березы каменной. Плодоношение в июле - сентябре, встречается часто. Известные местонахождения: окр-ти г. Магадана - Нагаевская сопка (MAG 2709); Ольский - окр-ти пос. Армань (MAG 1468), пос. Янский (MAG 2171), Мотыклейские горячие источники (MAG 2708), о. Недоразумения (MAG 4092), о. Спафарьева (MAG 4006) и Омсукчанский - пос. Омсукчан (MAG 1469) районы.

Распространение в России: Европейская часть, Западная и Восточная Сибирь, Дальний Восток.

Общее распространение: все континенты, кроме Антарктиды. Олла.
Антропогенные местообитания, на гниющих остатках и мусоре. Плодоношение в августе, встречается редко. Известные местонахождения: Ольский район - П-ов Кони (MAG 2706). Изначально был указан как Cyathus striatus (Huds.) Willd. (Сазанова, 2009).

Распространение в России: Европейская часть, Урал, Западная и Восточная Сибирь, Дальний Восток (Приморский край).

Общее распространение: все континенты, кроме Антарктиды.

*Lycoperdon excipuliforme (Scop.) Pers. Дождевик булавовидный. Рис. 1.5.

Каменноберезняки, смешанные березоволиственничные и пойменные тополево-чозениевые леса, на почве, реже на валеже лиственных пород (березы). Плодоношение в июле-августе, встречается редко. Известные местонахождения: окр-ти г. Магадана - Нагаевская сопка (MAG 4885, 5147); Тенькинский - окр-ти полевой базы «Оротук» (MAG 4022a) и Среднеканский - окр-ти пос. Сеймчан (MAG 3241), правый берег р. Колыма близ устья р. Джегдян (MAG 4553a) районы.

Распространение в России: Европейская часть, Кавказ, Урал, Западная и Восточная Сибирь (в т. ч. Республика Саха (Якутия), Дальний Восток (Приморский и Хабаровский края, Чукотский $\mathrm{AO})$.

Общее распространение: Европа, Азия, Африка, Северная и Южная Америка, Новая Зеландия.

*Lycoperdon lambinonii Demoulin - Дождевик Ламбинона. Рис. 1.6.

Каменноберезняки, смешанные березоволиственничные и тополево-чозениевые леса, остепненные склоны, сосновые посадки, на почве, у основания стволов и на замшелых камнях. Плодоношение в июле - сентябре, встречается часто. Известные местонахождения: окр-ти г. Магадана - Нагаевская сопка (MAG 4237, 5126), окр-ти пос. Снежная Долина (MAG 3889); Ольский - окр-ти оз. Глухое (MAG 1467), п-ов Кони (MAG 3660), Хасынский - 152-й км федеральной трассы «Колыма» (MAG 3259), Среднеканский - окр-ти пос. Сеймчан (MAG 4003, 5136) и Сусуманский - пойма р. Делянкир (MAG 5144) районы.

Распространение в России: Европейская часть, Кавказ, Урал, Западная и Восточная Сибирь, Дальний Восток (Камчатский и Приморский края).

Общее распространение: Европа, Северная Америка.

*Lycoperdon lividum Pers. - Дождевик сизый. Рис. 1.7.

Остепненные склоны и хорошо прогреваемые луговины, на почве. Предпочитает ксерофильные местообитания и карбонатные породы. Пло- 
доношение в июле-августе, встречается редко. Известные местонахождения: окр-ти г. Магадана - Нагаевская сопка (MAG 5148); Среднеканский - устье руч. Арангас (MAG 4931), Тенькинский - окр-ти стационара «Контакт» (MAG 5167) районы.

Распространение в России: Европейская часть, Кавказ, Урал, Западная и Восточная Сибирь (в т. ч. Республика Саха (Якутия), Дальний Восток (Приморский край).

Общее распространение: встречается как в Северном (Европа, Азия, Северная Америка), так и Южном (Австралия, Новая Зеландия) полушариях.

Lycoperdon molle Pers. - Дождевик мягкий. Рис. 1.8 .

Каменноберезняки, лиственничники, пойменные тополево-чозениевые леса, зарастающие после золотодобычи отвалы, на почве, реже на замшелых камнях или трухлявой древесине. Предпочитает богатые перегноем почвы, но может расти и на более бедных. Плодоношение в июне - сентябре, встречается часто. Известные местонахождения: окр-ти г. Магадана - 17-й км федеральной трассы «Колыма» (MAG 4034), Нагаевская сопка (MAG 2695a, 5149); Ольский ср. теч. р. Челомджа (MAG 3994a), о. Завьялова (MAG 2956, 2980), Северо-Эвенский - окр-ти пос. Северо-Эвенск (MAG 5031), Сусуманский поймы р. Берелех (MAG 5160) и р. Делянкир (MAG 5140) районы.

Распространение в России: Европейская часть, Кавказ, Западная и Восточная Сибирь (в т. ч. Республика Саха (Якутия), Дальний Восток (Амурская обл., Еврейская АО, Приморский и Хабаровский края, Сахалинская обл., Чукотский АО).

Общее распространение: Европа, Азия, Северная Америка.

Lycoperdon nigrescens Pers. - Дождевик чернеющий. Рис. 1.9.

Каменноберезняки, березово-лиственничные и тополево-чозениевые леса, лиственничные редколесья, разреженные кедровостланиковые заросли, приморские луга, кустарничковые тундры и остепненные сообщества, на почве, кочках и злаковых дерновинах. Вид с широким экологическим диапазоном. Плодоношение в июле сентябре, встречается часто. Известные местонахождения: окр-ти г. Магадана - Нагаевская сопка (MAG 2162, 2689, 2693), склон Горнолыжной базы (MAG 2694); Ольский - окр-ти оз. Глухое (MAG 1463) и оз. Чистое (MAG 2696), 94-й км трассы Магадан - Яна (MAG 2163), Янский лиман (MAG 4948), ср. теч. р. Челомджа (MAG 4011), о. Спафарьева (MAG 3990), о. Завьялова (MAG 3021), Хасынский - 152-й км Колымской трассы (MAG 3258), Сусуманский - окр-ти г. Сусуман (MAG 4806), окр-ти пос. Мяунджа (MAG
5156), 795-й км федеральной трассы «Колыма» (MAG 5153), пойма р. Делянкир (MAG 5138), окр-ти оз. Момонтай (MAG 5158, 5162), Тенькинский - стационар «Контакт» (MAG 5151) районы.

Распространение в России: Европейская часть, Кавказ, Урал, Западная Сибирь, Дальний Восток (Амурская обл., Еврейская АО, Камчатский (Корякия), Приморский и Хабаровский края, Чукотский $\mathrm{AO})$.

Общее распространение: Европа, Азия, Северная Америка, Африка (средняя).

*Lycoperdon niveum Kreisel - Дождевик белоснежный.

Горные кустарничковые тундры, на высоте 1100 м н. у. м., на каменистой почве среди дриады (Dryas ajanensis). Плодовые тела образует в июле - августе, встречается редко. Известные местонахождения: Хасынский район - Ольское плато (MAG 4587, 4588), Яблоновый перевал (MAG 5042).

Распространение в России: Кавказ, Урал, Западная и Восточная Сибирь.

Общее распространение: север Европы, Азия и Северная Америка.

Lycoperdon perlatum Pers. - Дождевик жемчужный. Рис. 1.10.

Склоновые каменноберезняки и ольховники, долинные лиственничные леса и редколесья, смешанные березово-лиственничные и пойменные тополево-чозениевые леса, сосновые посадки, остепненные склоны, антропогенные местообитания (газоны, зарастающие от 3олотодобычи отвалы), на почве, реже на гумифицированной древесине (валежнике, опилках, пнях). Плодоношение в июле-августе, встречается часто. Известные местонахождения: окрти г. Магадана - Нагаевская сопка (MAG 1464, 2159, 2688, 2690, 2695, 2697), склон Горнолыжной базы (MAG 2687, 4232a, 4235), окр-ти пос. Снежная Долина (MAG 2691, 2692), газон города (МАG 2699), 17-й км федеральной трассы «Колыма» (MAG 3854); Ольский - п-ов Кони (MAG 4242), Янский лиман (MAG 4019), ср. теч. р. Челомджа (MAG 3994, 5040), низовья p. Кава (MAG 4750), Хасынский - окр-ти стационара «Рангифер» (MAG 3999), 152-й км Колымской трассы (MAG 3260), Тенькинский - верховья р. Кюненбелях (MAG 3987), окр-ти полевой базы «Оротук» (MAG 1466, 4025, 4026), стационара «Контакт» (MAG 5172), Среднеканский - окр-ти пос. Сеймчан (MAG 5124), верховья р. Колыма близ устьев p. Джегдян (MAG 4553) и р. Суксукан (MAG 3384), Сусуманский - 795-й км трассы «Колыма» (MAG 5150), долина р. Делянкир (MAG 5139), окр-ти приисков «Ударник» (MAG 5142, $5163)$ и «Большевик» (MAG 5143), окр-ти 
о3. Момонтай (MAG 5152) и Ягоднинский - окрти пос. Дебин (MAG 4629) районы.

Распространение в России: Европейская часть, Кавказ, Урал, Западная и Восточная Сибирь (в т. ч. Республика Саха (Якутия), Дальний Восток (Амурская обл., Еврейская АО, Камчатский и Хабаровский края, Чукотский АО).

Общее распространение: встречается на всех континентах.

*Lycoperdon radicatum Durieu et Mont. [ $\equiv$ Bovistella radicata (Durieu et Mont.) Pat.] - Дождевик укореняющийся.

Приморские луга, на почве. Плодоношение в августе-сентябре, встречается редко. Известные местонахождения: Ольский район - окр-ти оз. Соленое (MAG 2157).

Распространение в России: Европейская часть, Дальний Восток (Сосин, 1973). Общее распространение: Европа, Азия, Северная Африка, Северная Америка.

*Lycoperdon rupicola Jeppson, E. Larss. and M. P. Martín - Дождевик скальный.

Разреженные приморские кедровостланиковые заросли, на песчаной почве среди мхов. Плодоношение в сентябре, встречается редко. Недостаточно изученный вид. Известные местонахождения: Ольский район - 94-й км трассы Магадан - Яна (MAG 2163).

Распространение в России: Западная Сибирь, Дальний Восток (Хабаровский край).

Общее распространение: Европа (Норвегия, Швеция), Азия.

Lycoperdon umbrinum Pers. - Дождевик умбровый. Рис. 1.12.

Каменноберезняки и ольховники, остепненные склоны и осинники, наледные долины, пойменные тополево-чозениевые леса, сосновые посадки, на почве, реже на задернованных замшелых камнях и гнилушках, у основания стволов деревьев. Плодоношение в июле - сентябре, встречается часто. Известные местонахождения: окр-ти г. Магадана - окр-ти пос. Снежная Долина (MAG 3807), Новая Веселая, распадок Кедровый ключ (MAG 3555), близ птицефабрики «Северная» (MAG 2168), Нагаевская сопка (MAG 5146); Ольский - п-ов Кони (MAG 3988), о. Завьялова (MAG 2955), Тенькинский - окрти полевой базы «Оротук» (MAG 3256, 3279), 153-й км Тенькинской трассы (MAG 5168) и Сусуманский - пойма р. Делянкир (MAG 5141, 5173) районы.

Распространение в России: Европейская часть, Кавказ, Западная и Восточная Сибирь (в т. ч. Республика Саха (Якутия), Дальний Восток (Амурская обл., Камчатский, Приморский и Хабаровский края, Сахалинская обл., Чукотский АО).

Общее распространение: Европа, Азия, Северная и Южная Америка.
Nidularia deformis (Willd) Fr. - Гнездовка бесформенная. Рис. 1.13.

Антропогенные местообитания, на гниющем, чаще привозном пиломатериале хвойных пород, старом строительном мусоре; редко в высокопойменных лесах на отмерших ветвях березы. Плодоношение в августе - сентябре, встречается не часто. Известные местонахождения: окрти г. Магадана - распадок Кедровый ключ (MAG 2710, 2813), 23-й км Колымской трассы, p-он Орбиты (MAG 4369); Ольский - окр-ти оз. Соленое (MAG 2172), долина p. Кава (MAG 4801) и Тенькинский - пойма р. Колыма близ полевой базы «Оротук» (MAG 4616) районы. Ранее образцы значились под синонимичным названием Nidularia pulvinata (Schwein.) Fr.

Распространение в России: Европейская часть, Западная Сибирь.

Общее распространение: Европа, Азия, Северная Америка, Австралия.

\section{Пop. BOLetaleS, Сем. Paxillaceae}

\section{Alpova sp. - Альпова.}

Разреженные чистые ольховниковые заросли или лиственничные редколесья, каменноберезняки, кедровостланики с включениями ольховника. Плодоношение в июле - сентябре, встречается редко. Известные местонахождения: окр-ти г. Магадана - Новая Веселая (MAG 1994), п-ов Старицкого, руч. Холодный (MAG 3573); Нагаевская сопка (MAG 4600), район Орбиты (MAG 4923).

\section{Сем. Rhizopogonaceae}

Rhizopogon cf. roseolus (Corda) Th. M. Fr. Ризопогон розоватый.

Разреженные заросли кедрового стланика, лиственничники и тополевники с кедровым стлаником, в песчаной почве. Плодоношение в июле - сентябре, встречается редко. Известные местонахождения: Ольский - 94-й км трассы Магадан - Талон (MAG 1341, 1995, 1996), долина p. Кава (MAG 5057), Среднеканский - окр-ти пос. Сеймчан (MAG 1343) и Тенькинский - окрти стационара «Контакт» (MAG 5164) районы.

\section{Сем. Suillaceae}

***Suillus gastroflavus Zvyagina, Rebriev, Sazanova et E. F. Malysheva - Гастромасленок желтый.

Увлажненные смешанные с ивами лиственнично-березовые леса, зеленомошные лиственничные редколесья, пойменные ивовые низины с молодыми лиственницами, на почве среди печеночных и зеленых мхов. Плодоношение в августе, встречается редко, иногда образует скученные группы до 20 базидиом. Известные местонахождения: Среднеканский - окр-ти пос. Сеймчан (MAG 3480, 4434, 5121, 5122) и Тенькинский - полевая база «Оротук» (MAG 1339) районы. 
Распространение в России: Дальний Восток (Магаданская область).

Общее распространение: Азия. Новый для науки и Евразии вид.

\section{Пор. GEASTRALES, Сем. Geastraceae}

Geastrum minimum Schwein. - Земляная звездочка малая. Рис. 1.14.

Сухие остепненные склоны и лиственничные редколесья, на песчаной или щебнистой почве. Приурочен к выходам базальтовых и карбонатных пород. Плодоношение в июне - сентябре, встречается редко. Известные местонахождения: Среднеканский - г. Замковая (MAG 2170, 4500, 4558), Арангасская гряда (MAG 2711) и Хасынский - бассейн p. Малтан близ месторождения Агатовское (MAG 2169), ср. теч. р. Армань близ ООПТ «Базальтовый» (MAG 3800) районы.

Распространение в России: Европейская часть, Западная и Восточная Сибирь, Дальний Восток (Приморский край).

Общее распространение: указан для всех континентов, кроме Антарктиды.

Sphaerobolus stellatus Pers. - Сфероболюс звездчатый. Рис. 1.15.

Смешанные с ольховником леса, посадки сосны обыкновенной, на валежных стволах ольховника (Duschekia fruticosa) и сосны (Pinus sylvestris). Плодоношение в августе-сентябре, встречается редко. Известные местонахождения: окр-ти г. Магадана - склон Горнолыжной базы (MAG 2173), Новая Веселая, распадок Кедровый ключ (MAG 2174), Орбита (MAG 4328), окр-ти пос. Снежная Долина (MAG 3743).

Распространение в России: Европейская часть, Западная и Восточная Сибирь, Дальний Восток (Приморский край).

Общее распространение: указан для всех континентов, кроме Антарктиды.

\section{ОБСУЖДЕНИЕ}

В конспекте (Сазанова, 2009) и последующих публикациях (Сазанова, 2012, 2015) для Магаданской области приводилось 18 видов гастеромицетов. В основном это хорошо определяемые виды, как самые обычные (B. nigrescens, L. perlatum, $L$. pyriforme, C. leave и др.), так и редкие ( $G$. minimum, Rh. roseolus, $S$. stellatus).

В результате проведенной ревизии удалось выявить 26 таксонов, из которых 12 видов новые для региона, 1 - новый для Восточной Азии и 1 новый для науки секотиоидный вид. Значительно расширены представления о видовом разнообразии родов Bovista (5 видов) и Lycoperdon (11 видов). Среди них присутствуют виды с широкими ареалами, приуроченными к бореальной зоне ( $B$. aestivalis, L. lambinonii, L. nigrescens), и арктоальпийские, бореально-арктоальпийские виды, указанные для северных регионов Евразии или Се- верного полушария (B. limosa, L. niveum). В ксерофильных местообитаниях предпочитает расти $L$. li-vidum, нитрофильных - B. plumbea. В результате просмотра коллекции ряд видов, указанных в публикациях, не нашли подтверждения и переведены в разряд вышеперечисленных. В частности, L. frigidum и B. paludosa, ранее отмеченные для о. Завьялова, отнесены к L. nigrescens (var. peckii?) и B. limosa. Но эти виды имеют потенциальную возможность быть обнаруженными. Идентификация некоторых образцов вызвала затруднения (в том числе и образец под названием Disciseda candida), для них требуется наиболее тщательное исследование.

Внесены изменения в список видов рода $\mathrm{Cal}$ vatia. Указанные ранее виды C. candida и C. utriformis не нашли подтверждения в сборах. Из кальватий наиболее распространенным по всему северу Дальнего Востока является арктобореальный вид C. turneri, который встречается как в лиственничниках, так и в приморских и горных тундрах, поднимаясь до высоты 1600 м н. у. м. Значительно реже на прибрежных территориях растет арктоальпийский вид $C$. cretacea.

Среди болетоидных гастеромицетов из Магаданской области описан новый для науки вид масленка (искусственный род Gastrosuillus) с секотиоидным (закрытым) плодовым телом -S. gastroflavus (Crous et al., 2019). Вид растет в увлажненных сообществах с лиственницей. По генетическим характеристикам тесно связан с группой серых маслят (ближе всего к S. flavus). Это третий известный во всем мире секотиоидный вид масленка (2 вида указаны для Северной Америки) и первый таксон - для Евразии. Для образцов из родов Alpova, Rhizopogon не удалось определить видовую принадлежность. В последнее время систематика многих групп, в том числе ризопогонов, пересматривается, впоследствии будут сделаны уточнения на видовом уровне. Ранее образцы приводились под названием $R$ h. roseolus (Corda) Th. M. Fr.

Некоторые виды гастеромицетов достаточно редкие. В новое издание Красной книги Магаданской области (2019) внесены G. minimum, L. lividum - индикаторы остепненных склонов и $L$. niveum - редкий представитель горных тундр. Редок для Азиатской России L. rupicola, известный из Алтайского и Хабаровского краев (Ребриев и др., 2018). Малоизученным редким видом для регионов с холодным климатом является B. limosa, внесенная в дополнительный список к Красной книге Ханты-Мансийского АО - Югры (2013).

На территории Государственного природного заповедника «Магаданский» отмечено лишь 6 видов гастероидных базидиомицетов: B. limosa, L. lambinonii, L. molle, L. nigrescens, L. perlatum, L. pyriforme. 
Гастероидные базидиомицеты предпочитают открытые хорошо прогреваемые места, поэтому часто встречаются в разреженных лесах и редколесьях, по обочинам лесных дорог, на открытых полянах. Большинство видов отмечено в естественных местообитаниях, преимущественно лесных сообществах (L. excipuliformis, L. lambinonii, L. molle, L. umbrinum), тундрах (C. creta$c e a, L$. niveum) или на остепненных склонах $(L$. lividum, G. minimum). Некоторые встречаются и в долинах, и в горах (B. nigrescens, C. turneri, $L$. nigrescens). Рудеральным местообитаниям отдают предпочтение B. plumbea, C. leave, C. olla, $N$. deformis. Ряд видов может расти как в естественных, так и нарушенных местообитаниях (B. aestivalis, B. tomentosa, L. perlatum и др.). Распределение видов по растительным сообществам складывается примерно в таком соотношении: в хвойных лесах обнаружено 11 видов, пойменных -12 , каменноберезняках и лесах с участием березы - 11, на остепненных участках 8 , в горных тундрах -4 , приморских тундрах и на лугах -7 , в антропогенных местообитаниях -11 .

По приуроченности к субстратам большинство выявленных видов - почвенные сапротрофы $(68 \%)$, значительно меньшая часть развивается на подстилке и древесине. К ксилосапротрофам относится L. pyriforme, который, помимо валежа и пней, может расти на уплотненной галечнопесчаной и каменистой почве по отсыпкам, газонам и обочинам дорог, перерабатывая скрытые древесные остатки и образуя плотные мицелиальные тяжи. Учитывая столь разную экологическую приуроченность, некоторые образцы значились как Bovista pusilla (Batsch) Pers., отмеченная также для многих регионов России. В современной системе объем этого вида существенно изменился. На отмершей древесине растут $N$. deformis, S. stellatus, и некоторые дождевики ( $L$. exipuliformis, L. umbrinum) могут использовать в качестве субстрата гумифицированную древесину. Самый распространенный в регионе вид $L$. perlatum характеризуется широкой экологической адаптивностью; предпочитая почву, может расти и на подстилке, и на полуразрушенной древесине. Болетоидные гастеромицеты относятся к микоризообразующим грибам: Rhizopogon sp. вступает в симбиоз с хвойными породами, в данном случае с кедровым стлаником, Alpova sp. - с ольховником, S. gastroflavus - с лиственницей.

В географическом плане большинство видов широко распространены по всему миру как в долготном, так и широтном градиентах. 14 видов встречаются в Северном и Южном полушариях, 8 - в Голарктике, 2 - Палеарктике. Часть видов отмечена на сопредельных с Магаданской областью территориях. Из перечисленного спи- ска 12 видов указаны для территории Республики Саха (Якутия), 7 - для Хабаровского края, 9 - для Чукотского АО, 8 - для Камчатского края. Эти данные говорят о недостаточной изученности микобиоты Северо-Востока Азии, где инвентаризация гастероидных грибов далека от завершения.

В результате ревизии коллекции выявлены лишь основные виды биоты гастероидных базидиомицетов гипоарктической тайги Магаданской области, и не исключаются находки новых и более редких видов.

Авторы искренне признательны всем коллегамбиологам и геологам, грибникам-любителям за помощь в сборах гастероидных грибов Магаданской области.

Работа выполнена в рамках Государственных заданий для Института биологических проблем Севера ДВО РАН: «Инвентаризация и классификация таксономического и пространственного разнообразия растений и растительных сообществ Севера Дальнего Востока России (№ гос. регистрации AAAAA 17-117122590002-0) и для Южного научного центра РАН: «Структурно-функциональная организация и динамика равнинных ландшафтных биоценозов юга России в условиях изменения климата и антропогенного воздействия» (проект AAAAA19-119011190176-7).

\section{ЛИТЕРАТУРА}

Агафонова Н. Н., Ребриев Ю. А., Гашков С. И. Гастероидные базидиомицеты Томской области // Микология и фитопатология. 2011. Т. 45. Вып. 3. С. 221227.

Андреев A. В. Эталоны природы ОхотскоКолымского края. Магадан : СВНЦ ДВО РАН, 2013. $322 \mathrm{c}$.

Горбунова И. А., Ребриев Ю. А. Новые сведения о биоте гастеромицетов Алтае-Саянской горной области // Растительный мир Азиатской России. 2016. № 2 (22). C. 3-7.

Горбунова И. А., Ребриев Ю. А. Редкие виды гастероидных базидиомицетов России // Там же. 2017. № 2 (26). C. 3-9. DOI: 10.21782/RMAR1995-24492017-2(3-9)

Красная книга Магаданской области. Редкие и находящиеся под угрозой исчезновения виды животных, растений и грибов. Магадан : Охотник, 2019. 356 с.

Красная книга Ханты-Мансийского автономного округа - Югры: животные, растения, грибы. Екатеринбург : БАСКО, 2013. 460 с.

Ребриев Ю. А., Двадненко К. В. Гастеромицеты рода Bovista в России // Микология и фитопатология. 2017. Т. 51. Вып. 6. С. 365-374.

Ребриев Ю. А. Гастеромицеты рода Calvatia в России // Там же. 2013. Т. 47. Вып. 4. С. 231-239.

Ребриев Ю. А. Гастеромицеты рода Geastrum в России // Там же. 2007. Т. 41. Вып. 2. С. 139-151.

Ребриев Ю. А. Гастеромицеты рода Lycoperdon в России // Там же. 2016. Т. 50. Вып. 5. С. 302-312.

Ребриев Ю. А., Морозова О. В., Свищ Л. Г. Гербарий грибов Ботанического института им. В. Л. Кома- 
рова РАН. IX. Гастероидные базидиомицеты // Там же. 2010. Т. 44. Вып. 5. С. 486-489.

Ребриев Ю. А., Булах Е. М., Горбунова И. А., Ерофеева E. A. Редкие виды гастеромицетов из Азиатской части России // Микология и фитопатология. 2018. Т. 52. Вып. 5. С. 349-355. DOI: 10.1134/ S0026364818050069

Сазанова Н. А. Макромицеты Магаданской области. Магадан : СВНЦ ДВО РАН, 2009. 196 с.

Сазанова Н. А. Новые виды в микобиоте Магаданской области // Вестник СВНЦ ДВО РАН. 2015. № 1. C. 69-76.

Сазанова Н. А. Первые сведения по грибам острова Завьялова // Там же. 2012. № 4. С. 93-99.

Север Дальнего Востока. М. : Наука, 1970. 488 с.

Синельникова Н. В., Пахомов М. Н. Сезонная жизнь верховий Колымы. М. : Тов.-во науч. изданий КМК, 2015. 329 c.

Синельникова Н. В. Эколого-флористическая классификация растительных сообществ верховий Колымы. Магадан : СВНЦ ДВО РАН, 2009. 214 с.
Сосин П. Е. Определитель гастеромицетов СССР. Л. : Наука, 1973. 163 с.

Швариман С. В., Филимонова Н. В. Флора споровых растений Казахстана. Т. 6. Гастеромицеты Gasteromycetes. Алма-Ата : Изд-во АН КазССР, 1970. $318 \mathrm{c}$.

Юриев Б. А. Проблемы ботанической географии Северо-Восточной Азии. Л., 1974. 159 с.

Crous P. W., Carnegie A. J., Wingfield M. J., et al. Fungal Planet description sheets: 868-950 // Persoonia. 2019. Vol. 42. P. 291- 473. https://doi.org/10.3767/ persoonia.2019.42.11

Kreisel $H$. Checklist of the gasteral and secotioid basidiomycetes of Europe, Africa and the Middle East // Österreichische Zeitschrift für Pilzkunde. 2001. Vol. 10. P. 213-311.

Volobuev S. V., Bolshakov S. Yu., Shiryaev A. G., et al. New Species for Regional Mycobiotas of Russia. 4. Report 2019 // Микология и фитопатология. 2019. Т. 53, № 5. С. 261-271. DOI: 10.1134/ S0026364819050076

Поступила в редакциию 04.10.2019 2.

Поступила после доработки

\title{
GASTEROMYCETES OF THE MAGADAN OBLAST
}

\author{
N. A. Sazanova', Yu. A. Rebriev ${ }^{2}$ \\ ${ }^{1}$ Institute of Biological Problems of the North, FEB RAS, Magadan \\ ${ }^{2}$ Southern Scientific Centre of Russian Academy of Sciences, Rostov-on-Don
}

\begin{abstract}
The article presents the results of processing the long-term collection of gasteroid basidiomycetes of Magadan Oblast, stored in the Herbarium of the Institute of Biological Problems of the North, Far East Branch, Russian Academy of Sciences (MAG). Data have been obtained on 26 taxa of 3 orders, among which both widespread and rare species are noted. 12 new species have been identified for the region; 1, for East Asia; and 1, for Eurasia. Information on species diversity of the genera Bovista and Lycoperdon has been significantly expanded, and the list of species genus Calvatia has been amended.
\end{abstract}

Keywords: gastromycetes, biodiversity, rare species, Magadan Oblast, north of Russia's Far East.

\section{REFERENCES}

Agaphonova, N. N.; Rebriev, Yu. A.; Gashkov, S. I., 2011, Gasteroid Basidiomycetes of Tomsk Oblast, Mycology and Phytopathology, 45, 3, 221-227 [In Russian].

Andreev, A. V., 2013, Nature Paragons of the OkhotskKolyma Country, Magadan, NESC FEB RAS [In Russian].

Crous, P. W.; Carnegie, A. J.; Wingfield, M. J.; Sharma, R.; Mughini, G.; Noordeloos, M. E.; Santini, A., Shouche, Y. S.; Bezerra, J. D. P.; Dima, B.; Guarnaccia, V.; Imrefi, I.; Jurjević, Ž.; Knapp, D. G.; Kovács, G. M.; Magistà, D.; Perrone, G.; Rämä, T.; Rebriev, Y. A.; Shivas, R. G.; Singh, S. M.; Souza-Motta, C. M.; Thangave, R.; Adhapure, N. N.; Alexandrova, A. V.; Alfenas, A. C.; Alfenas, R. F.; Alvarado, P.; Alves, A. L.; Andrade, D. A.; Andrade, J. P.; Barbosa, R. N.; Barili, A.; Barnes, C. W.; Baseia, I. G.; Bellanger, J.-M; Berlanas, C.; Bessette, A. E.; Bessette, A. R.; Biketova, A. Yu.; Bomfim, F. S.; Brandrud, T. E.; Bransgrove, K.; Brito, A. C. Q.; Cano-
Lira, J. F.; Cantillo, T.; Cavalcanti, A. D.; Cheewangkoon, R.; Chikowski, R. S.; Conforto, C.; Cordeiro, T. R. L.; Craine, J. D.; Cruz, R.; Damm, U.; de Oliveira, R. J. V.; de Souza, J. T.; de Souza, H. G.; Dearnaley, J. D. W.; Dimitrov, R. A.; Dovana, F.; Erhard, A.; Esteve-Raventós, F.; Félix, C. R.; Ferisin, G.; Fernandes, R. A.; Ferreira, R. J.; Ferro, L. O.; Figueiredo, C. N.; Frank, J. L.; Freire, K. T. L. S.; García, D.; Gené, J.; Gęsiorska, A.; Gibertoni, T. B.; Gondra, R. A. G.; Gouliamova, D. E.; Gramaje, D.; Guard, F.; Gusmão, L. F. P.; Haitook, S.; Hirooka, Y.; Houbraken, J.; Hubka, V.; Inamdar, A.; Iturriaga, T.; Iturrieta-González, I.; Jadan, M.; Jiang, N.; Justo, A.; Kachalkin, A. V.; Kapitonov, V. I.; Karadelev, M.; Karakehian, J.; Kasuya, T.; Kautmanová, I.; Kruse, J.; Kušan, I.; Kuznetsova, T. A.; Landell, M. F.; Larsson, K.-H.; Lee, H. B.; Lima, D. X.; Lira, C. R. S.; Machado, A. R.; Madrid, H.; Magalhães, O. M. C.; Majerova, H.; Malysheva, E. F.; Mapperson, R. R.; Marbach, P. A. S.; 
Martín, M. P.; Martín-Sanz, A.; Matočec, N.; McTaggart, A. R.; Mello, J. F.; Melo, R. F. R.; Mešić, A.; Michereff, S. J.; Miller, A. N.; Minoshima, A.; Molinero-Ruiz, L.; Morozova, O. V.; Mosoh, D.; Nabe, M.; Naik, R.; Nara, K.; Nascimento, S. S.; Neves, R. P.; Olariaga, I.; Oliveira, R. L.; Oliveira, T. G. L.; Ono, T.; Ordoñez, M. E.; Ottoni, A. de M.; Paiva, L. M.; Pancorbo, F.; Pant, B.; Pawłowska, J.; Peterson, S. W.; Raudabaugh, D. B.; Rodríguez-Andrade, E.; Rubio, E.; Rusevska, K.; Santiago, A. L. C. M. A.; Santos, A. C. S.; Santos, C.; Sazanova, N. A.; Shah, S.; Sharma, J.; Silva, B. D. B.; Siquier, J. L.; Sonawane, M. S.; Stchige, A. M.; Svetasheva, T.; Tamakeaw, N.; Telleria, M. T.; Tiago, P. V.; Tian, C. M.; Tkalčec, Z.; Tomashevskaya, M. A.; Truong, H. H.; Vecherskii, M. V.; Visagie, C. M.; Vizzini, A.; Yilmaz, N.; Zmitrovich, I. V.; Zvyagina, E. A.; Boekhout, T.; Kehlet, T.; Lassøe, T.; Groenewald, J. Z., 2019, Fungal Planet Description Sheets: 868-950, Persoonia, 42, 291- 473, https://doi. org/10.3767/persoonia.2019.42.11

Gorbunova, I. F.; Rebriev, Yu. A., 2016, New Data on the Gasteromycete Biota of the Altay-Sayan Mountain Region, Plant Life of Asian Russia, 2 (22), 3-7 [In Russian].

Gorbunova, I. F.; Rebriev, Yu. A., 2017, Rare Species of Gasteromycetes in Russia, Ibid., 2 (26), 3-9 [In Russian], DOI:10.21782/RMAR1995-2449-20172(3-9)

Kreisel, H., 2001, Checklist of the Gasteral and Secotioid Basidiomycetes of Europe, Africa and the Middle East, Österreichische Zeitschrift für Pilzkunde, 10, 213-311.

North of the Far East, 1970, Moscow, Nauka [In Russian].

Rebriev, Yu. A., 2007, Gasteromycetes of the Genus Geastrum in Russia, Mycology and Phytopathology, 41, 2, 139-151 [In Russian].

Rebriev, Yu. A., 2013, Gasteromycetes of the Genus Calvatia in Russia, Ibid., 47, 4, 231-239 [In Russian].

Rebriev, Yu. A., 2016, Gasteromycetes of the Genus Lycoperdon in Russia, Ibid., 50, 5, 302-312 [In Russian].

Rebriev, Yu. A.; Bulakh, E. M.; Gorbunova, I. A.; Erofeeva E. A., 2018, Rare Species of Gasteromycetes in Asian
Part of Russia, Mycology and Phytopathology, 52, 5, 349355 [In Russian]. DOI: 10.1134/S0026364818050069

Rebriev, Yu. A.; Dvadnenko K. V., 2017, Gasteromycetes of the Genus Bovista in Russia, Ibid., 51, 6, 365-374 [In Russian].

Rebriev, Yu. A.; Morosova O. V.; Svisht L. G., 2010, Fungi Herbarium of the Botanical Institute n. a.V. L. Komarov RAS, IX, Gasteroid Basidiomycetes, Ibid., 44, 5, 486-489 [In Russian].

Red Book of Magadan Oblast, Rare and Endangered Species of Animals, Plants, and Fungi, 2019, Magadan, Okhotnik [In Russian].

Red Book of the Khanty-Mansi Sutonomous Okrug - Yugra : Animals, Plants, Fungi, 2013, Yekaterinburg, Basko [In Russian].

Sazanova, N. A., 2009, Macromycetes of Magadan Oblast, Magadan, NESC FEB RAS [In Russian].

Sazanova, N. A., 2012, The First Data on Macromycetes of Zavyalov Island, Vestnik NESC FEB RAS, 4, 9399 [In Russian].

Sazanova, N. A., 2015, New Species in the Mycobiota of Magadan Oblast, Ibid., 1, 69-76 [In Russian].

Schwartzman, S. R.; Filimonova, N. M., 1970, Flora of the Spore Plants of Kazakhstan, 6, Gasteromycetes, Alma-Ata, AS KazSSR [In Russian].

Sinelnikova, N. V., 2009, Ecological and Floristic Classification of Plant Communities of the Kolyma Upper Reaches (North-East of Russia), Magadan, NESC FEB RAS [In Russian].

Sinelnikova, N. V.; Pakhomov, M. N., 2015, Seasonal Life in the Kolyma Upper Reaches, Moscow, KMK Scientific Press Ltd. [In Russian].

Sosin, P. E., 1973, Key to the Gasteromycetes of the USSR, Leningrad, Nauka [In Russian].

Volobuev, S. V.; Bolshakov, S. Yu.; Shiryaev, A. G; Sazanova, N. A.; Rebriev, Yu. A.; Ezhov, O. N.; Vlasenko, V. A.; Vlasenko, A. V.; Kalinina, L. B.; Stavishenko, I. V.; Zmitrovich, I. V., 2019, New Species for Regional Mycobiotas of Russia. 4. Report 2019, Mycology and Phytopathology, 53, 5, 261-271 [In Russian], DOI : 10.1134/ S0026364819050076.

Yurtsev, B. A., 1974, Problems of Botanical Geography of Northeast Asia, Leningrad, Nauka [In Russian]. 